\title{
STRATEGI PEMASARAN MOBIL MEREK DAIHATSU PADA DEALER DAIHATSU JEMBER
}

\author{
Shinta Nurafni Untari ${ }^{1}$, Sutrisno Djaja ${ }^{1}$, Joko Widodo ${ }^{1}$ \\ ${ }^{1}$ Program Studi Pendidikan, Fakultas Keguruan dan Ilmu Pendidikan, Universitas Jember \\ e-mail: sutrisnodjaja.fkip@unej.ac.id
}

\begin{abstract}
Abstrak
Penelitian ini dilakukan untuk mengetahui strategi pemasaran yang digunakan oleh Dealer Daihatsu Jember. Metode penentuan lokasi penelitian menggunakan metode purposive area yaitu di Dealer Daihatsu Jember. Penentuan subjek dan informan dalam penelitian ini ditentukan secara sengaja subjek yang akan diteliti. Subjek dalam penelitian ini adalah supervisor Dealer Daihatsu Jember dan Informan tambahan dalam penelitian ini adalah sales Dealer Daihatsu Jember. Metode pengumpulan data yang digunakan terdiri dari metode obesrvasi, wawancara dan dokumen. Analisis data yang digunakan dalam penelitian ini terdiri dari beberapa tahap, yaitu reduksi data, penyajian data, dan penarikan kesimpulan. Hasil penelitian menunjukkan bahwa Dealer Daihatsu Jember berada pada kuadran I yaitu posisi perusahaan yang mendukung strategi agresif, maka perusahaan berada pada posisi yang baik untuk menggunakan kekuatan internalnya untuk dapat memanfaatkan peluang yang ada sehingga strategi yang harus diterapkan dalam kondisi ini adalah mendukung kebijakan pertumbuhan yang agresif (growth oriented strategy). Strategi agresif merupakan strategi perusahaan yang bertujuan untuk memperluas pasar. Cara yang dapat digunakan Dealer Daihatsu Jember yaitu dengan strategi penetrasi pasar dan pengembangan pasar. Dimana untuk strategi penetrasi pasar (Market Penetration Strategy) dapat dilaksanakan dengan melakukan kegiatan promosi penjualan yang intensif dan efektif. Sedangkan untuk strategi pengembangan pasar (Market Penetration Strategy) dapat dilaksanakan dengan meningkatkan dan mempertahankan brand image mobil Daihatsu.
\end{abstract}

Kata Kunci: Strategi pemasaran dan Analisis SWOT

\section{PENDAHULUAN}

Perkembangan dunia usaha yang penuh persaingan menuntut perusahaan untuk semakin inovatif dalam mengeluarkan produk yang sekiranya disukai konsumen. Tanpa inovasi, produk suatu perusahaan akan ditinggalkan konsumen dalam persaingan dengan produk-produk lain yang semakin memenuhi pasar. Di lain pihak konsumen juga semakin kritis terhadap apa yang mereka terima dan harapkan dari sebuah produk. Jika ternyata tidak sesuai dengan harapan pelanggan, perusahaan tidak hanya akan kehilangan kepercayaan pelanggan tetapi juga berpotensi akan kehilangan pelanggan potensial. Pelanggan yang puas akan terus melakukan pembelian, dan pelanggan yang tidak puas akan menghentikan pembelian produk bersangkutan.

Industri otomotif merupakan salah satu industri yang sangat pesat perkembangannya di dunia termasuk di Indonesia. Ini disebabkan kebutuhan manusia akan transportasi sangat berpengaruh terhadap kegiatan masyarakat secara langsung. Kebutuhan akan alat transportasi ini membuat pasar otomotif nasional dewasa ini mengalami kemajuan yang cukup pesat. Hal ini terjadi karena munculnya inovasi produk - produk baru baik mobil impor (built-up) maupun mobil-mobil produksi dalam negeri sehingga memicu persaingan dalam dunia otomotif. Peningkatan inovasi dan suplai tersebut membuat dealer-dealer dari berbagai merek kendaraan kini semakin gencar mempromosikan produk baru.

Dalam memasarkan produknya, perusahaan harus menentukan cara efektif yang dapat dijadikan sebagai strategi untuk menarik konsumen agar membeli produk yang ditawarkan. Hal ini yang akan menentukan keberhasilan suatu perusahaan serta sebagai langkah awal dalam memahami keadaan dan permintaan pasar. Semakin banyak barang yang mampu menjangkau pasar maka akan semakin 
berkembang suatu perusahaan. Perkembangan industri otomotif ini diyakini dapat terus berlangsung karena volume penjualan kendaraan nasional yang terus meningkat. Seiring dengan meningkatnya daya beli masyarakat, maka permintaan akan suatu barang atau jasa juga ikut meningkat baik secara kualitas maupun kuantitasnya. Hal ini yang mendorong para produsen untuk bersaing memasarkan barang dan jasa yang mereka miliki. Berbagai cara dan strategi pemasaran pun dilakukan oleh para produsen agar meningkatkan hasil penjualan.

Strategi pemasaran merupakan titik tolak untuk berhasilnya produksi secara besar-besaran dan merupakan sarana yang berhubungan dengan konsumen. Persaingan bisnis otomotif roda empat di Indonesia masih di kuasai oleh merek Jepang yaitu Toyota, Daihatsu, Honda, Suzuki dan Mitsubishi yang setiap tahun selalu menduduki peringkat 5 besar penjualan mobil terbanyak di Indonesia. Hal ini dikarenakan mobil-mobil buatan Jepang sudah mempunyai brand dan citra yang baik bagi masyarakat Indonesia. Dibidang penjualan, Mobil merek Daihatsu memiliki beberapa kompetitor dari perusahaan lain seperti Toyota, Honda dan Suzuki.

Dealer Daihatsu Jember merupakan salah satu dealer resmi mobil Daihatsu yang berdiri di kabupaten jember. Selain showroom dealer Daihatsu Jember juga memberikan pelayanan lain seperti bengkel, servis, dan menyediakan spare part serta aksesoris asli mobil Daihatsu. Dealer Daihatsu merupakan salah satu dealer yang memiliki mobil LCGC (Low Cost Green Car) dengan harga murah di antara merek-merek mobil lainnya. Selain itu segmentasi pasar Dealer Daihatsu Jember juga sangat luas dari kelas atas hingga kelas menengah. Menurut hasil observasi mobil Daihatsu merupakan salah satu mobil yang diminati oleh masyarakat jember, hal ini terbukti dari volume penjualan mobil Daihatsu yang menduduki posisi kedua dengan volume penjualan mobil terbanyak di kabupaten jember.

Berdasarkan data volume penjulaan Dealer Daihatsu Jember dari tahun 2014-2016 mengalami kenaikan dan penurunan pada setiap bulannya. Salah satu penyebab penjualan setiap bulannya mengalami kenaikan dan penurunan dikarenakan persaingan mobil baru yang semakin kompetitif dan tidak stabilnya perekonomian masyarakat. Untuk meningkatkan volume penjualan perusahaan perlu menggunakan strategi pemasaran yang efektif dan efisien untuk menjaga kelangsungan hidup perkembangan perusahaan. Dalam membangun sebuah strategi pemaaran yang tepat bagi suatu perusahaan harus disesuaikan dengan kondisi dan situasi lingkungan pemasaran saat ini.

Sebuah perusahaan dalam memasuki dan menghadapi persaingan dipasar, maka dibutuhkan peranan strategi. Strategi pemasaran sangat penting dilakukan oleh dealer Daihatsu jember sebagai upaya dalam memperkenalkan produk-produk yang dimilikinya kepada masyarakat (konsumen). Selain itu juga keberhasilan Dealer Daihatsu Jember dalam kegiatan pemasaran tercemin dari kemampuan perusahaan dalam menempatkan produknya pada masyarakat atau konsumen. Dealer Daihatsu Jember mencoba memperluas pangsa pasarnya dan menarik pelanggan dengan cara mempengaruhi sikap konsumen agar bersedia membeli produk-produk yang dimiliki oleh Dealer Daihatsu Jember.

Semakin banyaknya persaingan dalam bidang usaha yang sama, maka perusahaan harus benar-benar mampu bersaing untuk menghindari kerugian. Apabila perusahaan tidak dapat mengikuti perkembangan saat ini, maka perusahaan tidak dapat bertahan dalam pasar. Salah satu upaya yang dapat dilakukan yaitu dengan menyusun kegiatan di bidang pemasaran. Pemasaran merupakan salah satu kegiatan pokok yang dilakukan oleh para pelaku usaha untuk mempertahankan kelangsungan perkembangan usahanya dan mampu bersaing, maka yang diperlukan adalah adanya manajemen pemasaran yang baik dan strategi pemasaran yang tepat. Akan tetapi dalam mencapai tujuan tersebut tidaklah mudah bagi perusahaan mempertahankan konsumen dengan banyaknya pesaing yang memiliki produk yang sejenis. Hal serupa juga disampaikan oleh salah satu sales dealer Daihatsu Jember orang yang menjalankan strategi pemasaran pada Dealer Daihatsu Jember :

"persaingan penjualan mobil baru di Jember saat ini semakin kompetitif, banyak brand mobil 
mengeluarkan jenis mobil LCGC (Low ost Green Car) yang membuat pasar otomotif saat ini menjadi dinamis. Saat ini Dealer Daihatsu Jember mempunyai mobil LCGC paling murah diantara dealerdealer yang lain. Sehingga kami menggunakan strategi pemasaran untuk mempengaruhi konsumen agar membeli produk yang kita miliki'.(Nt, $35 \mathrm{Thn})$

Strategi pemasaran diperlukan oleh setiap perusahaan yang menginginkan produk-produk yang mereka hasilkan dapat diterima di pasar sasaran. Setiap perusahaan dapat meningkatkan penjualan produknya dengan menggunakan strategi pemasaran yang efektif dalam meningkatkan pangsa konsumen yang ada. Strategi-strategi pemasaran yang dapat digunakan oleh perusahaan antara lain : STP (Segmnetasi, Targeting, Positioning) dan bauran pemasaran. Selain itu perusahaan juga dapat menggunakan analisis strategi pemasaran SWOT untuk mengetahui penggunaan strategi pemasaran yang tepat bagi perusahaan. Sebelum menentukan strategi pemasaran perusahaan dituntut untuk mengidentifikasi analisis lingkungan internal dan analisis lingkungan eksternal yang terjadi di dalam perusahaan. Hal ini dapat dijadikan sebagai acuan perusahaan dalam merumuskan strategi pemasaran yang sesuai dengan kondisi perusahaan.

Berdasarkan pemaparan latar belakang yang telah diuraikan di atas, maka peneliti tertarik untuk mengadakan penelitian dengan judul "Strategi Pemasaran Mobil Merek Daihatsu Pada Dealer Daihatsu Jember"

Terdapat penelitian sejenis yang dijadikan acuan bagi peneliti untuk melakuakan penelitian ini. Penelitian terdahulu yang berkaitan dengan strategi pemasaran pernah dilakukan oleh Maria Magdalyna (2003) yang berjudul "Analisis Penerapan Strategi Pemasaran Kendaraan Toyota (Studi Kasus PT Astrido Jaya Mobilindo Cabang Fatmawati), dan penelitian yang dilakukan oleh Eki Mauladi Rahman (2012) dengan judul "Analisis Penerapan Strategi Pemasaran Pada PT. Hadji Kalla (Toyota) Cabang Urip di Makassar".

Strategi pemasaran sangat penting peranannya dalam sebuah perusahaan, karena strategi pemasaran merupakan aspek utama sebelum barang dan jasa yang dihasilkan dapat dinikmati oleh konsumen. Menurut Tjiptono dkk (2008:28) strategi pemasaran merupakan rencana yang menjabarkan ekspektasi perusahaan akan dampak dari berbagai aktivitas atau program pemasaran terhadap permintaan produk atau lini produknya di pasar sasaran tertentu. Strategi Pemasaran menurut Wijayanti (2014:13) merupakan pedoman atau dasar pembuatan rencana marketing suatu produk dan taktik pemasaran. Strategi pemasaran ini juga digunakan sebagai pedoman untuk melakukan penjualan dan pendistribusian produk. Strategi pemasaran merupakan bagian penting dari sistem pemasaran secara keseluruhan dan merupakan langkah awal untuk membuat rencana pemasaran. Strategi pemasaran merupakan logika pemasaran dimana unit bisnis berharap untuk menciptakan nilai pelanggan dan mencapai hubungan yang menguntungkan. Perusahaan memutuskan pelanggan mana yang akan dilayaninya (segmentasi dan penetapan target) dan bagimana cara perusahaan melayaninya (deferensiasi dan positioning). Dipandu oleh strategi pemasaran, perusahaan merancang bauran pemasaran terintegrasi yang terdiri dari beberapa variabel yaitu produk, harga, tempat dan promosi (Kotler dan Armstrong, 2006:58)

Dalam strategi pemasaran terdapat unsur strategi persaingan dan unsur taktik pemasaran. Unsur strategi pemaaran meliputi segmentasi, targeting dan positioning. STP merupakan upaya memetakan pasar. Menurut Rangkuti (2014:102) unsur persaingan dapat dibedakan menjadi 3 yaitu segmentasi pasar, targeting dan positioning. Sedangkan unsur taktik pemasaran melipiti produk, harga, distribusi dan promosi. Menurut (Wijayanti, 2014:47) bauran pemasaran merupakan hasil kolaborasi empat unsur yang terdiri atas produk, harga, promosi dan distribusi dimana setiap unsurnya mempunyai peran dan fungsi yang berbeda, tetapi merupakan satu kesatuan yang tidak bisa terpisahkan satu sama lain. bauran pemasaran merupakan variabel-variabel yang dipakai oleh perusahaan sebagai sarana untuk 
memenuhi kebutuhan dan keinginan konsumen. Variabel yang terdapat didalamnya adalah produk, harga, distribusi, dan promosi. Keempat elemen ini sangat menentukan arah dari strategi pemasaran perusahaan. Unsur-unsur utama strategi pemasaran ini dapat diklasifi sesuai dengan tujuan perusahaan

Untuk mengetahui posisi perusahaan maka digunakan analisis SWOT. Analisis SWOT adalah suatu bentuk analisis untuk melihat kekuatan (Strenghts), kelemahan (Weaknes), peluang (Opportunities), dan ancaman (Threats) dari lingkungan perusahaan. Menurut Manap (2016:69) SWOT digunakan untuk mengidentifikasi seberapa besar dan kecilnya kekuatan dan kelemahan perusahaan serta seberapa besar dan kecilnya peluang dan ancaman yang mungkin terjadi.

\section{METODE}

Jenis penelitian ini adalah penelitian deskriptif kualitatif. Pendekatan kualitatif dengan jenis penelitian deskriptif ini bertujuan untuk menggambarkan suatu keadaan atau situasi yang sedang berjalan pada saat penelitian dilakukan. Dalam penelitian ini pendekatan deskriptif ditujukan untuk mendapat gambaran terperinci tentang strategi pemasaran yang digunakan oleh dealer Daihatsu Jember. Daerah penelitian ditentukan dengan menggunakan metode purposive area dengan menentukan lokasi di Dealer Daihatsu Jember. Penentuan subjek dan informan dalam penelitian ini ditentukan secara sengaja subjek yang akan diteliti. Subjek dalam penelitian ini adalah supervisor Dealer Daihatsu Jember dan Informan tambahan dalam penelitian ini adalah sales Dealer Daihatsu Jember. Untuk pengumpulan data peneliti menggunakan metode wawancara, observasi dan dokumen. Analisis data yang digunakan dalam penelitian ini terdiri dari beberapa tahap, yaitu reduksi data, penyajian data, dan penarikan kesimpulan.

\section{HASIL DAN PEMBAHASAN}

Hasil IFAS yang disusun berdasarkan hasil identifikasi dari kondisi lingkungan internal perusahaan berupa kekuatan dan kelamahan yang dimiliki Dealer Daihatsu Jember, didapat total nilai tertimbang sebesar 5,4 sehingga dari total tertimbang dapat disimpulkan bahwa perusahaan berada pada posisi kuat. Kondisi tersebut menunjukkan faktor internal Dealer DaIhatsu Jember telah mampu memanfaatkan kekuatannya dan mengatasi kelemahan yang dimilikinya dengan baik. Sedangkan Eksternal Factor Analysis Summary (EFAS) digunakan untuk mengetahui seberapa besar peranan dari faktor-faktor eksternal yang terdapat pada Dealer Daihatsu Jember. EFAS disusun berdasarkan hasil identifikasi dari kondisi lingkungan eksternal perusahaan berupa peluang dan ancaman yang dimiliki Dealer Daihatsu Jember. Berdasarkan hasil IFAS, didapat total nilai tertimbang sebesar 5,1. Hal ini menunjukkan Dealer Daihatsu mampu merespon faktor eksternal dengan memanfaatkan peluang yang ada untuk mengatasi ancaman.

Berdasarkan analisis IFAS dan EFAS kemudian dapat menentukan posisi perusahaan dalam diagram analisis SWOT untuk mengetahui strategi yang tepat berdasarkan posisi dalam kuadran tersebut. Adapun matrik diagram analisis SWOT sebagai berikut: 


\section{Diagram Analisis SWOT}

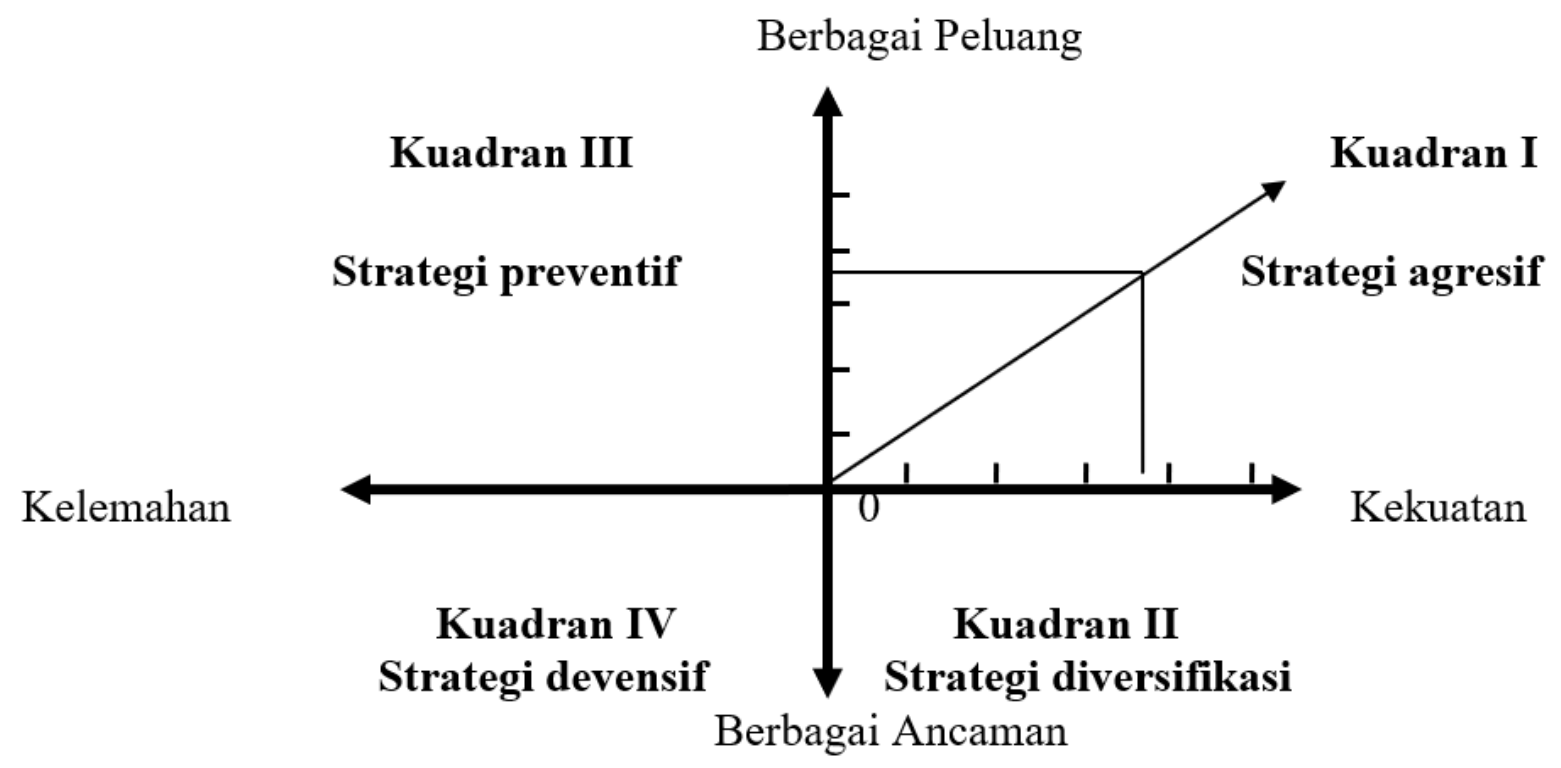

Berdasarakan hasil analisis perbandingan kekuatan (S) dan kelemahan (W) serta peluang (O) dengan ancaman (T) maka dapat digunakan formulasi analisis SWOT seperti yang ditunjukan pada Gambar 4.2. Hasil analisis SWOT menunjukkan bahwa strategi yang sesuai untuk Dealer Daihatsu Jember adalah strategi agresif (growth oriented strategy). Strategi agresif merupakan strategi perusahaan yang bertujuan untuk memperluas pasar.

\section{Pembahasan}

Berdasarkan analisis SWOT menunjukkan bahwa Dealer Daihatsu Jember berada pada kuadran I yaitu posisi perusahaan yang mendukung strategi agresif. Menurut Rangkuti (2014:21) ketika vector arah perusahaan berada di kuadran agresif (kuadran kanan atas) maka perusahaan berada pada posisi yang baik untuk menggunakan kekuatan internalnya untuk dapat memanfaatkan peluang yang ada sehingga strategi yang harus diterapkan dalam kondisi ini adalah mendukung kebijakan pertumbuhan yang agresif (growth oriented strategy).

Strategi agresif merupakan strategi perusahaan yang bertujuan untuk memperluas pasar. Cara yang dapat digunakan Dealer Daihatsu Jember yaitu dengan strategi penetrasi pasar dan pengembangan pasar. Dimana untuk strategi penetrasi pasar (Market Penetration Strategy) dapat dilaksanakan dengan melakukan kegiatan promosi penjualan yang intensif dan efektif. Sedangkan untuk strategi pengembangan pasar (Market Penetration Strategy) dapat dilaksanakan dengan meningkatkan dan mempertahankan brand image mobil Daihatsu. Brand image sangatlah penting bagi sebuah perusahaan untuk mengetahui apakah produk yang dimilikinya diterima oleh masyarakat. Hal ini didukung juga oleh pernyataan dari supervisor Dealer Daihatsu Jember.

"Brand image merupakan gambaran dari keberhasilan sebuah perusahaan dalam kegiatan pemasaran. Apabila produk dapat diterima dengan baik oleh masyarakat maka perusahaan dapat mengembangkan pasar yang lebih luas lagi" (Y, $32 \mathrm{Th})$

Berdasarkan dari posisi penentuan strategi pemasaran Dealer Daihatsu Jember menggunakan matrik SWOT maka strategi penetrasi pasar dan pengembangan pasar yang dapat digunakan Dealer Daihatsu Jember antara lain: 
a. Menjaga dan mempertahankan dalam memberikan pelayanan after sales service yaitu pelayanan setelah pembelian mobil yang maksimal kepada konsumen. Pelayanan ini berupa service mobil dan kemudahan dalam membeli spare part mobil Daihatsu.

b. Mengintensifkan promosi pada pasar konsumen yang dituju. Pasar konsumen mobil Daihatsu adalah masyarakat dari semua kalangan karena Daihatsu memiliki jenis mobil passenger dan mobil untuk berniaga.

c. Selalu berinovasi pada produk yang ditawarkan. Perusahaan harus selalu melakukan inovasi produk untuk menangkap peluang yang ada sesuai dengan kebutuhan konsumen

d. Menggunakan media sosial secara optimal untuk kegiatan pemasaran. Dewasa ini perkembangan media sosial bermunculan dengan berbagai fitur yang bisa dimanfaatkan untuk sarana untuk promosi. Promosi menggunakan media sosial bisa dikatakan lebih efekif karena menghapus jarak dan waktu.

e. Meningkatkan kemampuan SDM.

Dealer Daihatsu Jember dalam meningkatkan kemampuan SDM dapat dilakukan melalui pemberian pelatihan bagi karyawan untuk meningkatkan skill karyawan dalam upaya meningkatkan mekanisme penjualan dan meningkatkan kualitas pelayanan terhadap konsumen. Misalnya pelatihan personal sellingyaitu komunikasi langsung antara penjual dan calon pelanggan untuk memperkenalkan suatu produk kepada calon pelanggan dan membentuk pemahaman pelanggan terhadap produk sehingga pelangga memiliki ketertarikan untuk membeli.

f. Mensponsori local event. Dengan mensponsori local event masyarakat semakin mengetehui merek mobil Daihatsu tetapi juga untuk menjalin hubungan yang akrab dengan calon konsumen.

g. Meningkatkan hubungan baik ke pelanggan maupun calon customer. Dealer Daihatsu Jember ditengah persaingan yang ketat saat ini harus mampu memberikan pelayanan yang terbaik bagi pelanggan agar tetap loyal salah satunya dengan cara memberikan layanan via telepon/sms kepada pelanggan mengenai informasi produk yag ditawarkan, informasi prosedur pembelian melalui leasing atau cash.

h. Menambah jumlah tenaga pemasaran yang kompeten dibidangnya. Area pemasaran Dealer Daihatsu Jember yang luas membutuhkan tenaga pemasaran yang ahli dibidangnya sehingga kegiatan pemasaran yang dilakukan dapat optimal.

Strategi pemasaran yang tepat diterapkan oleh Dealer Daihatsu Jember untuk saat ini adalah strategi agresif atau growth oriented strategy. Pemilihan strategi ini diyakini dapat meningkatkan penjualan dan dapat lebih meningkatkan pangsa pasar yang ada, sehingga perusahaan dapat menarik minat konsumen untuk membeli mobil pada Dealer Daihatsu Jember dan mampu bersaing dengan Dealer lainnya di Kabupaten Jember.

\section{PENUTUP}

Berdasarkan hasil penelitian dan pembahasan yang sudah dilkukan oleh peneliti kepada informan utama mengenai strategi pemasaran yang dilakukan Dealer Daihatsu Jember, dapat disimpulkan berdasarkan analisis SWOT pada Dealer Daihatsu Jember posisi perusahaan berada pada kuadran I artinya strategi pemasaran yang sesuai untuk Dealer Daihatsu Jember adalah strategi agresif. Strategi agresif merupakan strategi perusahaan yang bertujuan untuk memperluas pasar. Cara yang dapat digunakan Dealer Daihatsu Jember yaitu strategi penetrasi pasar dan pengembangan pasar. Strategi pemasaran yang digunakan oleh Dealer Daihatsu Jember adalah dengan menentukan Segmentasi pasar, Target Pasar dan Positioning (STP) serta menerapkan taktik bauran pemasaran 
(marketing mix).

Berdasarkan kesimpulan dari penelitian ini maka dapat diberikan saran kepada Dealer Daihatsu Jember yaitu sebaiknya Dealer Daihatsu Jember diharapkan lebih optimal dalam melakukan kegiatan pemasaran dengan cara menambah tenaga pemasaran yang kompeten di bidangnya mengingat area pemasaran Dealer Daihatsu Jember yang luas serta Diharapkan Dealer Daihatsu Jember sering mengadakan pelatihan-pelatihan atau training agar antara sales training, sales junior dan sales senior memiliki kemampuan yang sama dalam melakukan kegiatan pemasaran sehingga dapat meningkatkan penjualan pada Dealer Daihatsu Jember.

\section{DAFTAR PUSTAKA}

Tjiptono, fandy. 2008. Pemasaran Strategik. Yogyakarta: Andi Publisher.

Wijayanti. 2014. Marketing Plan! Dalam Bisnis. Jakarta: PT Elex Media Komputindo.

Kotler dan Amstrong. 2006. Prinsip-Prinsip Pemasaran, Edisi ke-12. Jakarta: Erlangga.

Rangkuti, Freddy. 2014. Teknik Membedah Kasus Bisnis Analisis SWOT. Jakarta: PT Gramedia.

Manap, Abdul.H. 2016. Revolusi Manajemen Pemasaran. Jakarta: Mitra Wacana Media. 